Ristekdik (Jurnal Bimbingan dan Konseling)

Vol.6, No.2, 2021, hlm.213-218

DOI: http://dx.doi.org/10.31604/ristekdik.2021.v6i2.213-218

ISSN 2541-206X (online)

ISSN 2527-4244 (cetak)

\title{
PENGEMBANGAN E BOOK BIMBINGAN DAN KONSELING PADA MATERI KONSEP DIRI NEGATIF
}

\author{
${ }^{1}$ Rati Puspita Sari, ${ }^{2}$ Ramtia Darma Putri, ${ }^{3}$ Endang Surtiyoni \\ ${ }^{1,2,3}$ FKIP Bimbingan dan Konseling Universitas PGRI Palembang \\ ratipuspita831@gmail.com
}

\begin{abstract}
The purpose of this study was to determine the development of guidance and counseling e-books on negative self-concept material for students at MTs Negeri 2 Empat Lawang. This research uses the research \& development method. The development model carried out is ADDIE which consists of the analysis, design, development, implementation, and evaluation stages. The results of the study stated that the development of the e-book was declared very valid to be used in providing services to students after being tested for validity by a team of experts, namely media, material and educator experts. Based on the results of the practicality test, the guidance and counseling e-book was carried out through filling out questionnaires to students, so the guidance and counseling e-book on negative self-concept material was declared very practical.
\end{abstract}

Keywords: E-book, Guidance and Counseling, Negative Self Concept

\begin{abstract}
Abstrak: Tujuan penelitian ini adalah mengetahui pengembangan $e$-book bimbingan dan konseling pada materi konsep diri negatif untuk siswa di MTs Negeri 2 Empat Lawang. Penelitian ini menggunakan metode pengembangan (reseach \&development). Model pengembangan yang dilakukan adalah ADDIE yang terdiri dari tahap analysis, design, develeopment, implementation, dan evaluation. Hasil penelitian menyatakan bahwa pengembangan $e$-book dinyatakan sangat valid untuk digunakan dalam memberikan pelayanan kepada siswa setelah diuji kevalidan oleh tim ahli yaitu ahli media , materi dan pendidik. Berdasarkan hasil uji kepraktisan, e-book bimbingan dan konseling dilakukan melalui pengisian angket kepada siswa, maka $e$-book bimbingan dan konseling pada materi konsep diri negatif ini dinyatakan sangat praktis.
\end{abstract}

Kata Kunci : E-Book, Bimbingan dan Konseling, Konsep Diri Negatif

\section{PENDAHULUAN}

Perkembangan zaman yang dipenuhi dengan teknologi seperti saat ini membuat individu dapat memanfaatkannya semaksimal mungkin khususnya dibidang pendidikan. Menurut Undang-Undang Sisdiknas No. 23 Tahun 2003 pendidikan adalah usaha sadar dan terencana untuk mewujudkan suasana belajar dan proses pembelajaran agar siswa secara aktif mengembangkan potensi dirinya untuk memiliki kekuatan spiritual keagamaan, pengendalian diri, kepribadian, kecerdasaan, akhlak mulia, serta keterampilan yang di perlukan dirinya dan masyarakat. Sudarsana (2016) menjelaskan bahwa pendidikan bisa menjadikan sumber daya manusia lebih siap dalam menghadapi perubahan dan pembangunan suatu negara. Seperti di Negara, Amerika Serikat, Inggris, Jerman, Belanda, dan juga Jepang. Penghasilan sumber daya manusia yang baik membuat mereka mampu membangun negara mereka masuk dalam kategori negara maju. Perkembangan teknologi 
merupakan satu faktor yang ikut serta dalam dunia pendidikan. Seiring berkembangnya teknologi, semakin banyak siswa yang sudah mampu mengoperasikan perangkat komputer maupun gadget yang sangat berpengaruh dalam proses belajar. Hal tersebut sesuai dengan pernyataan Pane (2017:333) belajar dan pembelajaran merupakan sebuah bentuk edukasi yang menjadikan adanya suatu interaksi antara guru dengan siswa.

Pendidikan merupakan hal yang dianggap penting dan sangat berperan dalam mengembangkan potensi diri serta meningkatkan kualitas hidup baik secara individu maupun kelompok. Pengembangkan potensi diri individu digunakan untuk memahami dirinya sendiri, serta mengetahui kelebihan dan kekurangan yang dimiliki. Cara memahami diri sendiri disebut dengan konsep diri. Ardiyanti (2017:18) menjelaskan bahwa konsep diri merupakan gambaran menyeluruh mengenai bagaimana individu mempersepsikan dirinya sendiri. Setiap inividu memiliki konsep diri yang terdiri dari konsep diri postif dan konsep diri negatif. Konsep diri yang dimiliki tergantung pada pandangan individu terhadap diri yang sendiri. Berdasarkan hasil observasi pada bulan November 2020 di MTsNegeri 2 Empat Lawang masih ada siswa yang belum memahami apa itu konsep negatif dan masih ada siswa memiliki konsep diri negatif yang di tandai dengan siswa yang mudah marah jika dinasehati oleh guru, mencela orang lain didalam kelas, mengeluh jika diberikan tugas, dan merasa tidak di sukai orang lain yang berada disekitarnya. Hal ini dapat ditangani guru kelas dan di bantu oleh guru bimbingan dalam konseling dengan memberikan pelayanan secara maksimal dan lebih menarik dengan memanfaatkan kemajuan teknologi.

Proses pelayanan bimbingan dan konseling dilakukan oleh guru bimbingan dan konseling seharusnya dapat dikembangkan secara menarik sesuai dengan kemajuan teknologi. Kenyataan di lapangan menunjukan bahwa guru khususnya guru bimbingan dan konseling masih sering menggunakan metode konvensional tanpa dukungan media dalam memberikan layanan bimbingan dan konseling. Salah satunya adalah MTs Negeri 2 Empat Lawang. Sekolah ini merupakan salah satu sekolah di Kabupaten Empat Lawang yang masih menjalankan metode konvensional dalam memberikan pelayanan bimbingan dan konseling. Namun, pada masa pandemi covid19 mengharuskan guru bimbingan dan konseling memberikan pelayanan secara daring. Guru bimbingan dan konseling sedikit kesulitan dalam memberikan pelayanan dengan menggunakan media yang disajikan secara daring.

Waryanto, dkk (2017:3) menjelaskan bahwae-book adalah buku yang di desain ke dalam bentuk elektronik. Fitria \& Heliawan, (2017:5 menyatakan e-book adalah singkatan dari electronic book atau buku elektronik tidak lain adalah sebuah bentuk buku yang dapat di baca secara elektronis melalui komputer, $e$ book ini berupa file dengan format bermacammacam. Gaol, Servina, Supriyati (2019:2) 
menyatakan e-book singkatan dari electronic book adalah jenis buku elektronik yang berbentuk softcopy yang dapat dibaca melalui perangkat electronik seperti komputer, smartphone dan handphone.

Berdasarkan beberapa pengertian di atas peneliti berpendapat bahwae-book merupakan buku elektronik dengan format yang bermacam-macam sehinga e-book bisa di gunakan yang bisa di baca melalui perangkat eloktronik.

E-book merupakan media pembelajaran yang tidak lepas dari perangkat komputer, laptop, gadget dan lainya. Hal tersebut sesuai dengan simpulan Restiyowi \& Sanjaya, (2012) menyatakan bahwa e-book atau electronic book adalah buku teks yang di konversi menjadi format digital. E-book juga memiliki pengertian sebagai lingkungan belajar yang memiliki aplikasi yang mendukung database multimedia sumber daya intruksional yang menyimpan persentasi multimedia tentang topic. E-book ini bisa digunakan untuk bahan ajar dan untuk guru bimbingan dan konseling. E-book ini bisa digunakan sebagai media dalam pemberian layanan informasi yang memungkinkan siswa tidak merasa bosandalam proses pembelajaran.

Berdasarkan uraian di atas, peneliti tertarik untuk melakukan penelitian menggunakan pengembangan media dalam mengurangi konsep diri negatifpada siswa. Berkaitan dengan hal ini, maka judul pada penelitianini adalah "Pengembangan E-book Bimbingan dan Konseling pada Materi Konsep
Diri Negatif Untuk Siswa di MTs Negeri 2 Empat Lawang".

\section{METODE PENELITIAN}

Penelitian ini merupakan metode pengembangan (reseach \& development). Menurut Sugiyono (2018:297) reseach and development adalah metode penelitian yang digunakan untuk menghasilkan produk tertentu, dan menguji keefektifan produk tersebut. Produk yang dikembangkan bisa berupa produk dalam bidang pendidikan yang berupa bahan ajar untuk digunakan sebagai media dalam bimbingan dan konseling. Media yang dihasilkan dari pengembangan ini bisa digunakan sebagai media pemberian layanan contohnya layanan informasi.

Penelitian dilakukan di MTs Negeri 2 Empat Lawang di kelas VIII F, waktu penelitian pembuatan mediae-book selama 2 minggu dan implementasi e-book di MTs Negeri 2 Empat selama 1 hari menyesuaiakan dengan data yang diperlukan.

Model pengembangan yang dilakukan adalah ADDIE yang terdiri dari tahap analysis, design, develeopment, implementation, dan evaluation. Teknik pengumpulan data menggunakan angket, dan dokumentasi.

Teknik analisis data dapat dilakukan ketika data diproleh dari hasilvalidasi produk oleh tim ahli dan uji coba produk pada siswa. Data yang terkumpul diolah dan dianalisis menggunakan skala likert. Analisis dilakukan untuk melihat kelayakan produk yang telah dikembangkan. 
Widoyoko (2018:106) menyatakan bahwa penggunaan skala lima memiliki respon lebih baik sehingga dapat maksimal dalam memperoleh perbedaan sikap responden.

\section{HASIL PENELITIAN}

Hasil pengembangan e-book bimbingan dan konseling pada materi konsep diri negatif untuk siswa MTs Negeri 2 Empat Lawang yang dikembangakan dengan model ADDIE. Hasil penelitian sebagai berikut :

\begin{tabular}{|l|l|l|l|}
\hline No & Tim Ahli & Skor & Kriteria \\
\hline 1 & Media & 3.7 & Sangat valid \\
\hline 2 & Materi & 3.5 & Valid \\
\hline 3 & Pendidik & 3.8 & Sangat valid \\
\hline
\end{tabular}

Bersadarkan tabel di atas dinyatakan bahwa e-book dinyatakan Sangat Valid. Berdasarkan data validasi dari ahli materi dinyatakan Valid dengan skor rata-rata 3.5 dan e-book ini bisa diuji cobakan dalam proses pemberian layanan informasi kepada siswa mengenai konsep diri negatif. Hal ini sesuai dengan penyataan Astuti, (2015) bahwa dalam setiap pertimbangan pemilihan media perlu memperhatikan ketepatan dengan tujuan pembelajaran artinya media yang dipilih harus sesuai dengan tujuan yang harus dicapai, sehingga $e$-book yang dikembangkan sesuai dan sejalan dengan tujuan yang diharapakan tercapai oleh peneliti .Berdasarkan data hasil Validasi ahli media di peroleh hasil skor ratarata 3.7 dengan kriteria sangat valid.
Berdasarkan hasil uji kepraktisan ebook dilakukan dengan cara menyebarkan angket respon peserta didik pada kelas VIII F di MTs Negeri 2 Empat Lawang dengan skor hasil sebagai berikut :

\begin{tabular}{|l|l|l|l|}
\hline No & Aspek & $\begin{array}{l}\text { Rata- } \\
\text { Rata }\end{array}$ & Kriteria \\
\hline 1 & Aspek tampilan & 3,9 & $\begin{array}{l}\text { Sangat } \\
\text { Praktis }\end{array}$ \\
\hline 2 & Aspek penyajian & 3,9 & $\begin{array}{l}\text { Sangat } \\
\text { Praktis }\end{array}$ \\
\hline 3 & Aspek manfaat & 4 & $\begin{array}{l}\text { Sangat } \\
\text { Praktis }\end{array}$ \\
\hline \multicolumn{2}{|l|}{ Total Skor Rata-Rata } & 3,9 & $\begin{array}{l}\text { Sangat } \\
\text { praktis }\end{array}$ \\
\hline
\end{tabular}

Berdasarkan tabel di atas pada uji kepraktisan yang diperoleh aspek tampilan 3.9, aspek penyajian 3.9 aspek manfaat 4 dengan kriteria masing-masing yaitu sangat praktis hal ini dapat diartikan bahwa e-book yang dikembangkan sudah sesuai dengan tujuan yang akan dicapai dalam penelitian. Berdasarkan penyataanIpanripai (2017) bahwa adanya $e$ book dapat membantu para pemula dan e-book ini sangat praktis untuk dibawah kemana-mana.

\section{PEMBAHASAN}

Berdasarkan data dan hasil uji coba produk yang sudah diperoleh bahwae-book bimbingan dan konseling pada materi konsep diri ini sudah layak untuk digunakan sebagai media dalam proses pemberian layanan kepada siswa, dengan adanya $e$-book ini bisa menumbuhkan motivasi belajar kepada siswa karena suasana dan cara pemberian layanan sudah lebih menarik dan sesuai dengan kriteria. Sehingga sesuai dengan penyataan Arsyad (2011) bahwa proses belajar mengajar akan efektif dan efisien 
jika didukung dengan tersedianya media yang menunjang. Hal ini juga sesuai dengan pernyataan pribadi, dewi \& putri (2019:1) bahwa bahan ajar berperan sebagai medium yang menjadi perantara proses penyampaian pengetahuan dan keterampilan dari narasumber kepada orang yang belajar.

\section{SIMPULAN}

Berdasarkan hasil penelitian pengembangane-book bimbingan dankonseling pada materi konsep diri negatif yang telah dikembangkan oleh peneliti dan diimplementasikan pada siswa kelas VIII $\mathrm{F}$ MTs Negeri 2 Empat Lawang menggunakan model pengembangan ADDIE. Pengembangan e-book ini dinyatakan Sangat valid untuk digunakan dalam memberikan pelayanan kepada siswa setelah diuji kevalidan oleh tim ahli yaitu ahli media, materi dan pendidik. Berdasarkan hasil uji kepraktisan e-book yang dilakukan dengan cara pengisian angket kepada siswa, maka e-book bimbingan dan konseling pada materi konsep diri negatif ini dinyatakan

\section{Sangat Praktis.}

\section{DAFTAR RUJUKAN}

Ardiyanti, Niken. (2017). Peran Penting Konsep Diri Dalam Membentuk Track Record. Jakarta: Salemba Humanika.

Astuti, T. (2015). Pengembangan Media Pembelajaran kartun $3 d$ Berbasis Muvizu pada mata pelajaran Matematika kelas 1 di Sd lab School Unnes. Skripsi UNES semarang.

Arsyad, Azhar (2011) . Media Pembelajaran. Jakarta : PT Fitria. T.H \&Heliawan.
Y. A. (2017). Meningkatkan Kemampuan Mahasiswa Prodi Akuntansi Dalam Memahami Buku, Book Dan Artikel/ Jurnal Akuntansi Multipel Representasi. Jurnal Akuntansi dan Pajak, Vol 17, No. 02, 1412-629X.Raja Grafindo Persada

Gaol. M.L, Serevina \& Supriyanti. Y (2019) Media Pembelajaran Ebook Berbasis 3D Pageflip Pada Materi Suhu dan Kalori Dengan Model Pembelajaran discovery Learning. E-Journal Volume VIII.

Ipanripai, (2017). Rancangan Bangunan Media Pembelajaran Menggunakan Android Untuk Mata Kuliah Pemrograman Internet Menggunakan Magazine APP Maker. Jurnal ICT learning Vol. 3 No 1.

Pane, Aprida. (2017). Belajar dan Pembelajaran. FITRAH Jurnal Kajian Ilmu-Ilmu Keislaman Vol. 03 No. 2, 2442-6997.

Pribadi A B, Dewi ,Putri P (2019). Pengembangan Bahan Ajar. Tangerang Selatan: Universita Terbuka.

Restiyowi\&Sanjaya. M.G (2012). Pengembangan E-book Interaktif pada Materi Kimia Semester GenapKelas XI SMA. Unesa Journal of Chemical Education vol.1 No. 1, 130-135.

Sudarsana. I.K. (2016) Peningkatan Mutu Pendidikan Luar Sekolah Dalam UpayaPembangunan Sumber Daya Manusia. Jurnal Penjamin Mutu.

Sugiyono. (2018). Metodelogi Penelitian Kuantitatif, Kualitatif dan $R \& D$. Bandung: Alfabeta. 
Undang-Undang No 23 Tahun 2003 Tentang Sistem Pendidikan Nasional.

Widoyoko, E. P (2010). Evaluasi Program Pembelajaran Panduan Praktis Bagi Pendidik dan Calon Pendidik. Yogyakarta : Pustaka 